\title{
The Role Of Global Education In The 21 Century Slovak Schools
}

\author{
Beatrix Bačová \\ Faculty of Civil Engineering \\ University of Žilina (SLOVAKIA) \\ Eva Leláková \\ Faculty of Humanities \\ University of Žilina (SLOVAKIA)
}

\begin{abstract}
Globalization affects all areas of life, the life of teachers including. The teaching profession is usually understood as a mission. The role of a teacher is to develop knowledge, abilities and skills of pupils and students and thus influence their values and opinions. Teachers present basic attributes of human lives' interconnections to their students. They teach them to take into account the interests and living conditions of all people - to think in a global way. The authors of the present paper try to explain how the globalization influences teachers in their process of education and knowledge transfer and answer the questions dealing with the principles effecting the global education of both students and their teachers. They also point out that the work of teachers is not only very demanding but also significantly influencing the quality of the knowledge level of every society.
\end{abstract}

Key words: Globalization, teacher, global upbringing, lifelong education, 21 century.

\section{INTRODUCTION}

Globalization represents one of current trends in 21st century. It is a term that we encounter almost daily - we constantly read, listen and watch in media how globalization influences the world economy, determines the autonomy of individual states and affects the change of structures in the world. It is dealt with by historians, political scientists, sociologists and economists. From the historical point of view, globalization as an inevitable and natural process represents mutual interconnection and dependence of individual parts of the world system. [1] The contemporary world is influenced by global processes similarly like scientific and technological revolution once influenced the world in the area of informationcommunication technologies and development of production and transport (this caused, inter alia, deterioration of the environment). On one hand, globalization is an inevitable process, which is the result of the evolution of the world situation; on the other hand this process brings certain negatives. "Globalization produces extreme wealth for a small minority and growing poverty for more and more people. Consequently, financial and economic globalization leads to the widespread exclusion of entire nations and groups of people. The threat of social decline, anonymity of power structures and the speed of decision-making induce resignation and fear". [2] Globalization contributes to modernisation of the contemporary world and life. However, its process often runs in a non-transparent way and is therefore risky. Globalization extends to every area of our life - it extends also to teachers' lives and to the educational process where passing newly acquired knowledge to our pupils and students takes place. 


\section{GLOBALIZATION AS A TERM}

Even today there does not exist a unified definition of globalization. Exnerová defines globalization as an amount of various interrelated and mutually conditioned economical, technological, social, cultural and political aspects forming the essence of present contradictory processes. [3] In contrast, Antošová defines globalization as a process of increasing social interactions by which different locations are interconnected, i.e. events taking place in geographically remote areas affect events taking place at home. [4] Another possibility is to define the term globalization as a process of integrating a society to a higher geographical level.

\section{GLOBALIZATION AND EDUCATION}

There exist several important international documents declaring the significance of global education. We can find among them the documents of the United Nations Organisation Agenda 21 (1992), Millennium Declaration (2000), documents of the European Union European Consensus on Development (2005) and also the documents of the Council of Europe - The Maastricht - Global Education Declaration (2002) and the North- South Centre of the Council of Europe - Global Education Guidelines (2008).

The definition of global education was created by the association North- South Centre (The European Centre for Global Interdependence and Solidarity) in 2002:"Global education is education that opens people's eyes and minds to the realities of the globalised world and awakens them to bring about a world of greater justice, equity and human rights for all. Global education is understood to encompass development education, human rights education, education for sustainability, education for peace and conflict prevention and intercultural education; being the global dimension of education for citizenship". According to Development Education Association global education is, on the other hand, defined as an approach to obtaining education leading to a deeper understanding of diversity and imbalance in the world. [5]

Global education allows people to understand the interconnection between their lives and the lives of other people in the world and increases people's awareness of global economic, social, political and environmental aspects which influence them. It develops abilities, attitudes and values which are related to mutual cooperation of all people and contribute to the change of attitudes towards people's own lives. Furthermore, it strives for achieving greater justice in the world as it is based on the principles of solidarity, equity, integration and cooperation.

Initially, in the field of education, only a minimum space was given to the issue of globalization and global processes in Slovakia. [1] Global education existed only as an integral part of the official development cooperation of the state. As the beginning of the global development education in Slovakia can be considered the week of global education which took place in Košice in 2003. The central theme of this week was: "Conflict and safety: the world we live in, the world we want". [6] It was necessary for knowledge of human needs, regularities resulting from them and ways which threaten human living conditions to be included in education. Also knowledge of possibilities of the society development sustainability solutions and associated abilities and habits of a man had to be taken into consideration. In addition to these requirements, tolerance between nations and responsibility not only for the present but also for the future had to be accepted.

Global education became a part of the Program Declaration of the Government of Slovak Republic for the period of years 2010-2014. Similarly, the National Strategy for Global Education for years 2012-2016 was accepted as an official program document on 18 January 
2012 by the Government of the Slovak republic. Its main aim is to ensure citizens of the Slovak republic an access to information on global issues and issues of developing countries and motivate them towards an active approach while solving them. The document defines global education as "education that points out a global context in teaching (and learning). Thanks to global education there is an increase in awareness about global topics which concern every individual; there is also development of his/her critical thinking and a deeper understanding of the topics which influence the whole world. The topics of global education provide enough space for an individual to change his/her attitudes and strengthen awareness of his/her own role in the world". Global education motivates people to be responsible and educates them to acquire the values of an active "global citizen".

One important part of global education is represented by global development education which is understood as an educational attitude towards deeper understanding of diversity and inequity in the world. This type of education encourages everyone with no age limits to examine current problems (e.g. poverty) and their connection with everyday life.

Suchožková states that the UNESCO's International Commission on Education for the 21 Century defined four basic pillars of education - learning to know, learning to do, learning to live together and learning to be. [7] Global education works with eight basic mutually overlapping concepts: global citizenship, global interdependence, social justice, resolving conflicts, cultural diversity, values and attitudes, human rights and permanently sustainable development.

It is a process (see Fig.1) which

- begins with raising awareness of certain problems,

- creates a deeper understanding of them,

- encourages people to reflect on their own role in solving the problems and thus changes their attitudes and behaviour,

- motivates and empowers people to become active in a responsible way [8]

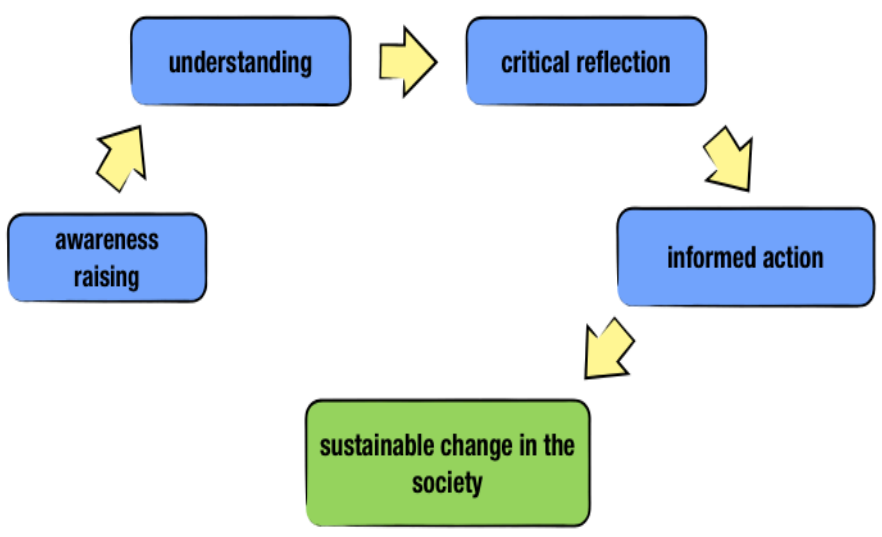

Fig. 1 The process of global education

In order to solve the problem of global education completely and successfully, corresponding basic, secondary and tertiary education is necessary. Since there is not a sufficient number of qualified teachers, present teachers need to have the possibility to complete their education in the field of global education, e.g. in the form of undertaking accredited innovative programmes of continual education. [9] Teachers should obtain adequate education - not in order to get degrees but to obtain knowledge which could be applied in practice. Nowadays it is important 
for global education to be incorporated into the educational process in the form of global dimension - incorporated into the already existing curriculum of individual subjects (social studies, geography, ethics, environmental education, multicultural and media education).

In 2006, thanks to a financial support of the SlovakAiD programme, many non-governmental organizations (e.g. Civic associations Človek v ohrození, Živica, eRko, Nadácia Integra, Nadácia Pontis, and many others) got grants and projects within which topics of poverty, fair trade, children' rights and others could be discussed at schools. At the same time, members of the stated organizations were training teachers, helping them to create methodical manuals, didactic materials, organise interactive expositions, etc.

In the past an educational process was understood only as a unilateral teacher- student influence. Nowadays, education of students is influenced by several factors. There is the aim to educate a personality with its own identity and value orientation, with respect to people and nature, cooperation, prosocial behaviour and national values. When fulfilling this aim, the teacher cannot be satisfied just with providing information about moral principles. He/she uses also adventure teaching which develops understanding and interiorization of moral norms. In the context of compulsory education, according to Lysý [10] there is a possibility to implement various programmes of civic education, educational programmes in the field of human rights or programmes in the field of intercultural, anti-racist, peace and global education and education for tolerance (see Fig.2)

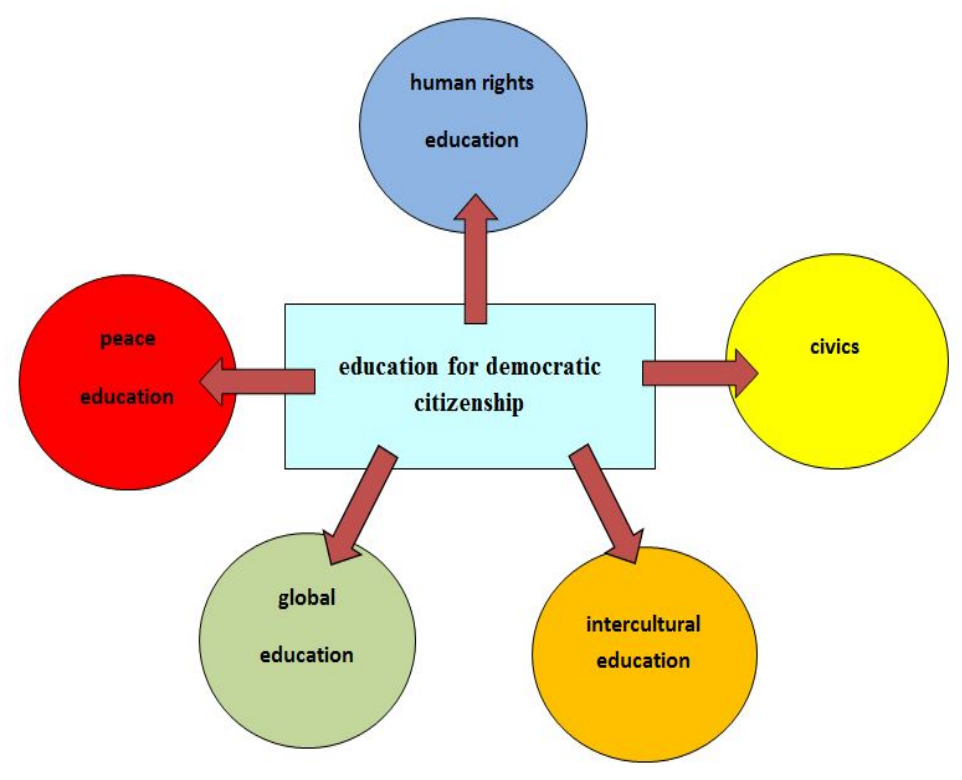

Fig. 2 Education for democratic citizenship and its parts

In Table 1 example activities of global education within individual compulsory subjects are stated. 
Table 1

\begin{tabular}{|l|l|}
\hline \multicolumn{1}{|c|}{ Subject } & \multicolumn{1}{c|}{ Global education - topics } \\
\hline History & $\begin{array}{l}\text { political power, democracy and human rights, global economy, international } \\
\text { business, and } \\
\text { poverty }\end{array}$ \\
\hline Geography & $\begin{array}{l}\text { consumption and production, natural sources, sustainable development and } \\
\text { environment }\end{array}$ \\
\hline Art and culture & peace and conflict \\
\hline English language & $\begin{array}{l}\text { sustainable development and environment, migration, transport and } \\
\text { travelling, man and nature, multicultural society, English speaking countries }\end{array}$ \\
\hline Biology & $\begin{array}{l}\text { sustainable development, political power, democracy and human rights, } \\
\text { quality of environment }\end{array}$ \\
\hline
\end{tabular}

Development of technology enables a continuous flow of information and knowledge between countries. Communication is faster than ever before. For work and study reasons, migration of population is increasing and thus changing demographic features of many countries. As a result of this process, new intercultural identities and communities come into existence. Cultural diversity and multiculturalism along with the reality of working life exist even in our country and require employees coming into contact with foreigners to have not only sufficient language knowledge but intercultural competence as well. That is why we can generally describe education as a complex interactive process in which there is a constant interaction and influence of two main participants - a teacher and a student, an educator and an educated person. The process of education is also influenced by other factors and for this reason some simplifications are used for its modelling. One of the most realistic models of an educational process is the model of J. Hendrich [11] which represents a traditional didactic triangle - the content of education, teacher and student enriched by an aim, organisational, material and methodical conditions (see Fig.3).

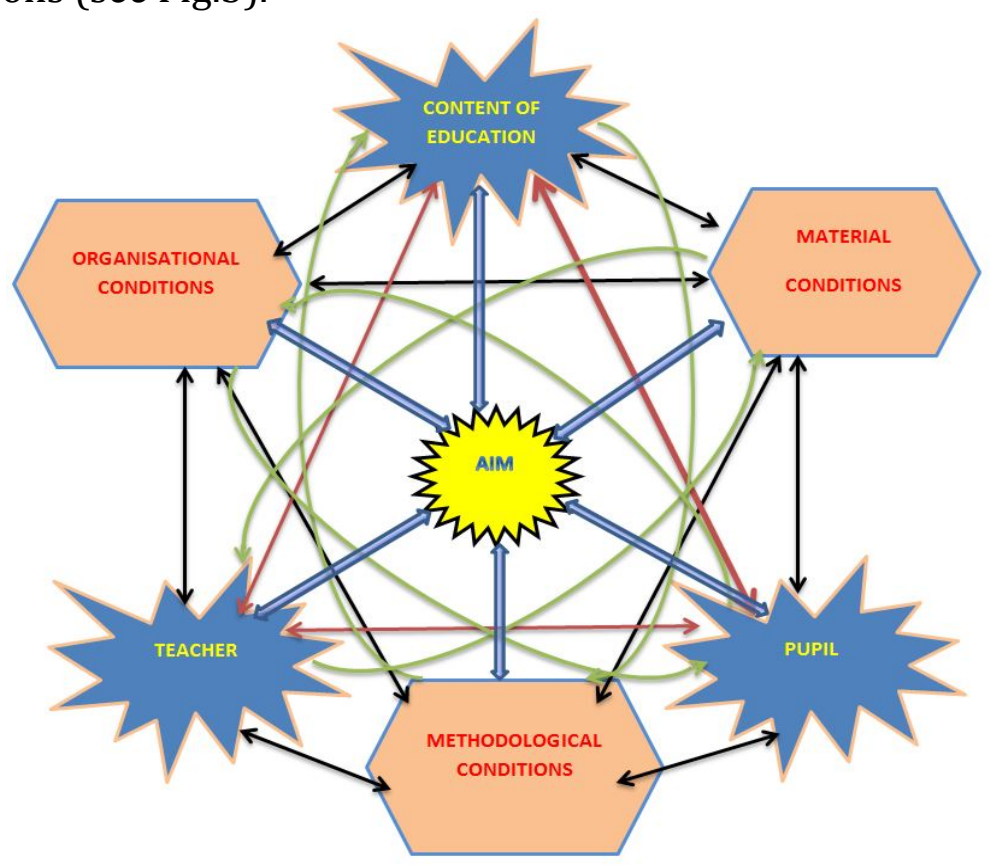

Fig. 3 Hendrich's model of an educational process 


\section{GLOBAL EDUCATION}

Global education is very closely related to global upbringing which represents a living process directly influencing students. Global upbringing points out a respect for the rights of students' personalities and a responsible and active approach to other people and environment. [12] Both global education and upbringing use traditional aims, methods and forms of education and emphasize active involvement of a student in an educational process. They also bring into focus positive motivation and stimulating environment in which a student has a feeling of safety and certainty; cooperates with others and through direct experience takes over responsibility for their work and for their results as well. [13] Motivating the students is one of the teachers' responsibilities and, undoubtedly, it is a fairly challenging task. [14]

In an educational process a teacher is supposed to create situations which are as close as possible to the situations of spontaneous learning. These situations can be later used for inner motivation of students, activation of their knowledge and submission of problematic and polemical task assignments in which their importance and usefulness for life are emphasized.

\section{GLOBALIZATION AND TEACHER}

Present-day students think at a higher level than their predecessors who were led to assessment, analysis, synthesis and application of knowledge acquired directly from their teacher. They use modern technologies, especially Internet. In Fig. 4 we can see "Google, yahoo" part of the student's brain where he/she stores knowledge obtained from the Internet. For students, Internet is often a place where they can find answers to almost all their questions, even those regarding their place in the modern globalized world

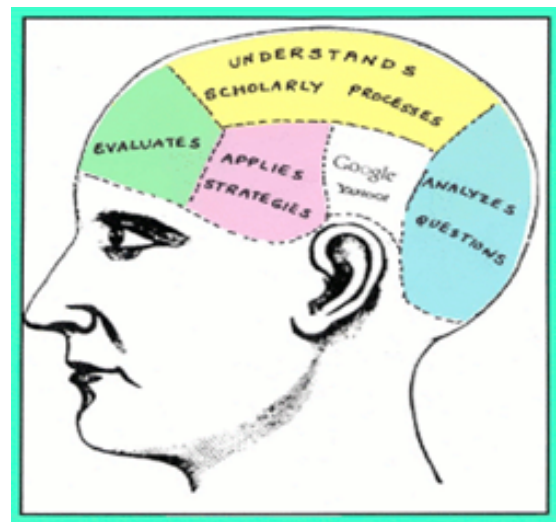

Fig. 4 The 21st Century Brain [15]

In this demanding search, in this process of distinguishing between important and correct knowledge and less important and insignificant one, a teacher should give them a helping hand. We have to realize that technology is not just an information carrier or a means that allows automatization of the educational process any more. Each teacher has to be aware of the complex influence of modern technologies on the educational process. Teachers should know why and when they can require from their students to memorize something that is easily found on the Internet. They should know the right boundary between focusing on facts and building competencies needed for the life in the 21st century. From the pedagogical point of view, we can speak about a higher level of Bloom's taxonomy.

The duty of a teacher is to develop knowledge, skills and abilities of students, and thus influence their values and attitudes. By his/her pedagogical activity a teacher helps students to 
understand the existence of interconnections of human lives, he/she teaches them to be aware of the interests and living conditions of all people, to think globally, and act locally.

It is difficult to find one right description of 21 century teacher. According to 0 'Gangel [16] personality of a teacher represents the highest system of organisation of the human being's mental life which regulates his/her action and purposeful behaviour in integration with the environment. A teacher, who is a decisive factor in the educational process, represents a live model for their students. They imitate him/her and try to identify with him/her. [17] In the educational process, a mature and balanced personality of a teacher with high moral standing is irreplaceable. [9] A teacher is the main factor; without him/her no education is possible. A teacher, in fact, works with the most precious social value - with a student. Education and qualification levels of people in a certain society are deciding factors of its development. Social importance of teacher's work interferes in all areas of human life. Unfortunately, nowadays his/her social status and prestige are not on an expected level.

Modern society expects from a teacher to have:

- a high professional level - a teacher has to know precisely the content of the curriculum of subject he teaches,

- professional competencies - a teacher has to master the principles, methods and forms of the educational process, and

- human and moral qualities which are not common for other members of population.

A teacher has to be assertive, emphatic, communicative, capable of accepting others' opinions and capable of self-reflection. S/he should create favourable social and emotional climate and work atmosphere, enthuse students for a certain idea and be able to work with IT technology. Nowadays, a teacher has to use this technology not only in the educational process but also in communication with students. [18]

The teacher's work is often referred to as the mission. A teacher develops knowledge, skills and abilities of individuals, influences their attitudes and values and has a direct impact on cognition of each society. In no other profession there are such high demands on the personality, demeanor and behavior that should be so strongly bound to immediate job performance. The following reasons have to be mentioned:

- there is no universal approach to fulfill a professional role of the teacher,

- students often imitate their teachers,

- teachers realize their professional tasks by using their own knowledge, abilities, linguistic expressions and experience,

- educational work of teachers is difficult to control from the outside; society is dependent to achieve the necessary control implemented by the teachers themselves.

When we deal with the professional activities of an "expert" teacher, his/her moral qualities and ethical dimension have to be emphasized. Ethical status of the teaching profession is inextricably linked to the relevant factors and the qualities of the moral value nature such as freedom and responsibility, pedagogical justice, professional pedagogical tact and authority. The teacher's authority is determined by his/her own human dimension, spiritual and moral personality status, culture of behavior as well as self-identification with the teaching profession. 
The effectiveness of the teacher's work is largely dependent on the quality of his/her teaching skills. Kyriacou [19] states that a teaching process can be effective only if the teacher's work fulfills the following conditions:

- it obtains and maintains student's attention to the teaching activity,

- it obtains and maintains student's motivation and effort to learn through learning activities,

- training activities must correspond with such type of student's learning which the teacher wants to have in the class.

- The teacher is supposed to know what the students need and what is helpful for them. The skills of the teacher are characterized by these features:

- are focused on achieving a certain specific objective,

- are typical for a specific context,

- require a precise design and sensitive adaptation,

- are obtained by training and practical activity.

According to Kyriacou [19] pedagogical skills can be defined as individual logically interconnected activities of a teacher which support the student's learning process. They are:

- knowledge,

- decision-making process, and

- action.

In general, basic pedagogical skills which contribute to successful teaching are described as:

- planning and preparation,

- implementation of the lesson,

- lesson management,

- classroom climate,

- discipline,

- evaluation of the student's achievement,

- reflection and evaluation of own work (self-reflection).

Application of pedagogical skills also depends on the teacher's personality. Teachers' attitudes to pedagogical work begin to form during their university studies and continue to develop especially during their teaching practice. Teachers' personalities are the results of their selfeducation - purposeful and systematic work on themselves. The results of these efforts are based on an inclusive approach comprising the following steps:

- self-reflection,

- self-evaluation,

- self-confidence,

- self-control,

- self-regulation,

- self-creation.

Self-reflection, which is an integral part of teachers' work, is very closely related to their competencies. The concept of competence means the power, its range, and ability to perform an activity. In relation to teachers' work, pedagogical-didactic, sociological and other competencies are defined. With changing circumstances and increasing demands on an effective educational process the teacher must apply information, learning, cognitive, interpersonal (social), communication and personal competencies. [13] 
A global teacher, who is supposed to prepare a student for an active participation in a globalized world, is according to Pike, Selby [12] required to:

- prefer a worldwide context over a local point of view while solving problems,

- bring the diversity and potential of various cultures to students,

- focus on future,

- allow students to obtain knowledge, come to conclusions and changes of their attitudes by an individual work,

- instil in students the trust in human abilities and possibilities,

- focus on a complex and steady development of personality,

- use a wide database of methods, forms and means of education,

- understand learning as a lifelong process,

- respect the rights of others, and adequately shift the responsibility for decisions on a group or a class,

- bring inter-subject relationships and connections closer to students and

- connect the class life with the school life, academic society life and community life.

The result of the present life is the fact that increasing aggression of children, violence against classmates and bullying are experienced in schools. These problems require a new approach of solving from teachers. They should be able to act preventively against the negatives which are not compatible with social norms, focus on communication with students, knowledge and understanding relationships between them and seek the reasons causing this behaviour. An integral part of the teacher's work should be a regular cooperation with the educational advisor, school psychologist, respectively with a special or social educator. [18]

To accomplish a constant development of skills in the stated areas, lifelong education should be a natural thing for a teacher. A good and quality teacher constantly needs to improve his practical activity and deal with new requirements that make his job a difficult but creative and interesting profession. [19] Thanks to lifelong education teachers can become creative people able to mediate new knowledge to their students, teach them how to think critically but creatively, how to learn rationally and how to use newly acquired knowledge and information effectively (see also Fig.5)

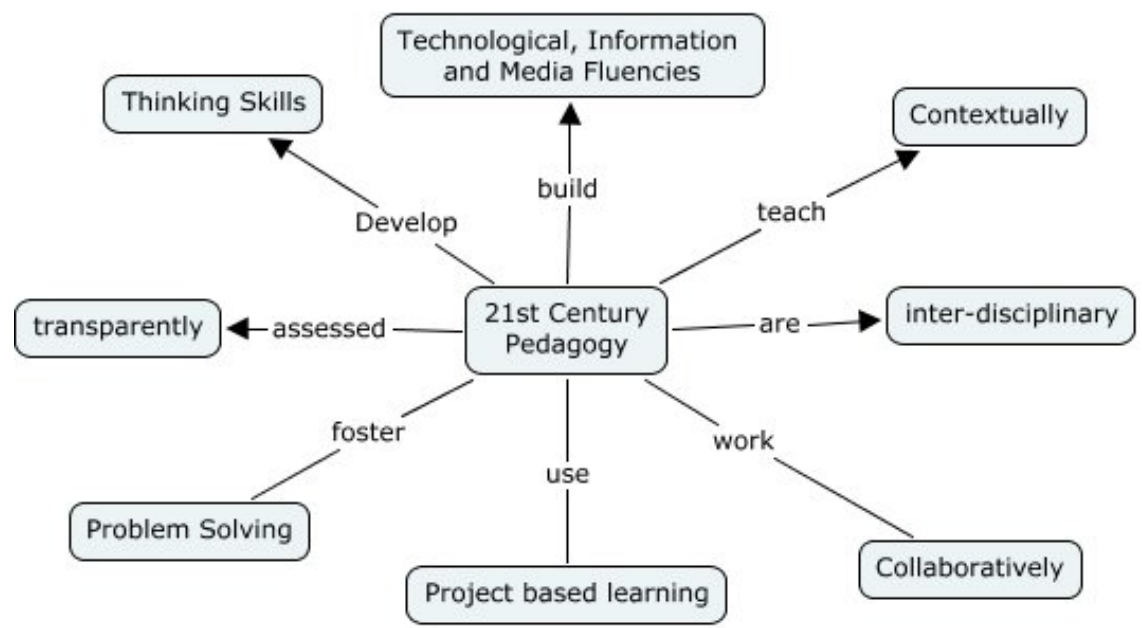

Fig. 5: The key features of 21 century pedagogy [20] 


\section{CONCLUSION}

As we stated before, education is a commodity but also the highest spiritual value. It goes through paradigms which more or less react to a wider context - to the social and cultural atmosphere. We have to realize that education is provided in difficult, constantly developing and changing conditions. A very low amount of experts are dedicated to the issue of global (development) education nowadays in Slovakia. This fact is caused by a total absence of global education at universities (it is supported only by several projects of Methodological and Pedagogical Centres). Creating the education, whose result will be a global teacher, is extremely difficult. It requires from the teacher to be not only enthusiastic but also to accept internally global education philosophy, a high level of trust, open communication and mutual cooperation. These facts need to be taken into consideration during future teachers' preparation. It is necessary to focus on:

- verbal and non-verbal communication competence,

- strengthening of critical thinking,

- development of the ability of active listening,

- preference of cooperative way of learning/teaching and interaction,

- personal experience and active involvement of students in the teaching/learning process,

- a facilitating way of preparation - participants are led to individual acquisition of knowledge, solution of problems and drawing conclusions,

- acceptance of certain styles' diversity,

- common education of teachers of different target groups,

- using the method of shock - revealing, recognizing and overcoming certain barriers in opinions and attitudes. [12]

However, not only creating conditions for future teachers but also innovations of an already ongoing educational process are the keys to the development of the 21st century teaching and learning skills.

Global education, as a lifelong educational process, significantly contributes to understanding of similarities and differences between the lives of people in developing and developed countries. It leads to acceptation of responsibility for creating the present world. [6] Regular and ongoing evaluation of this process is very important. Within the evaluation of the National strategy for global education, an annual monitoring of the tasks fulfillment is carried out. A rolling evaluation of the National strategy for global education is planned in 2014 and its final evaluation in 2016.

Nowadays it is clear to all of us that the next generation will need predominantly creativity and ability of lifelong education. The dynamics, with which the changes are going on in the educational process, emphasizes also the need of personal development of the teacher profile. "Teachers should be humane to their students and never underestimate them". [21] They have to be consistent and principled managers, authorities but not dictators for students. They have to be very patient with an open attitude to everything and able to make all students (including the most disobedient ones) cooperate. Despite the fact that recently, along with the classical IT technologies also digital books are promoted, the role of a teacher remains important and irreplaceable.

This paper has been written with the support of Cultural and Educational Grant Agency of Slovak Ministry of Education, project: K-15-001-00; 015ŽU-4/2015. 


\section{References}

1. Hulan, B. (2005). Je globalizácia morálna? In: Acta Humanica, Žilina, pp. 73-79.

2. Hulan, B. - Dzuriaková, J. (2007). Sociálna etika. Žilina: EDIS, 196 p.

3. Exnerová, V. (2005). Globálne problémy a rozvojová spolupráca. Praha: Člověk v tísni, 255 p.

4. Antošová, N. (2007). Globalizace a mezinárodní organizace. VŠB TU Ostrava, 209 p.

5. Think Global [online]. Available on: http://think-global.org.uk/. [cit. 2014 - 30 - 11].

6. Taldíková, E. (2011). Globálne vzdelávanie na Slovensku - doterajší vývoj a perspektívy - analýza. Bratislava: Slovenské centrum pre komunikáciu a rozvoj, 92 p.

7. Suchožková, E. (2013).Globálne vzdelávanie -vzdelávanie pre 21. storočie. Bratislava:MPC, 64 p.

8. What is global education. [online]. Available on: http://glen-europe.org/global-education/what-is-globaleducation [cit. $2014-03$ - 11].

9. Cabanová, V. (2012). Globalization trends and their impact on the transformation of school education in the Slovak republic. In: SVU and its role in the era of globalisation: transatlantic collaboration, innovation and preservation: selected papers. Highland Park, NJ, USA: Czechoslovak society of arts and sciences, pp.215-225

10. Lysý, J. (2007). Globálne (rozvojové) vzdelávanie (učebné texty). Bratislava: ALBUM, 180 p.

11. Hendrich, J. (1998). Didaktika cudzích jazykov. Praha: SPN, 498 p.

12. Pike, G., Selby, D. (1994). Globální výchova. Praha: Grada, 322 p.

13. Turek, I. (2005). Inovácie v didaktike. Bratislava: MPC, 199 p.

14. Metruk, R. (2014). Factors affecting L2 pronunciation. In: Journal of Interdisciplinary Philology. Žilina, 1/2014, pp. 13-21.

15. Purposeful Technology-Constructing Meaning in 21st Century Schools. [online]. Available on: http://purposefultechnology.weebly.com/why-is-digital-literacy-important.html [cit. 2014 - 13 - 11].

16. O`Gangel, K. (1995). Called to teach. USA: ASCI, Colorado Springs, 186 p.

17. Hupková, M., Petlák, E. (2004). Sebareflexia a kompetencie v práci učitel’a. Bratislava: IRIS, 135 p.

18. Chugurya, S., Szabadosová, S. (2009). Učitel' pre školu 21. storočia. Zvolen: OZ Pedagóg, Bratia Sabovci, s.r.o., pp.181-187.

19. Kyriacou, Ch. (2012). Klíčové dovednosti učitele. Cesty k lepšímu vyučování. Praha: Portál, 168 p.

20. 21 century pedagogy. [online]. Available on: http://edorigami.wikispaces.com/21st+Century+Pedagogy [cit. $2014-25$ - 11].

21. Dzuriaková, J. (2005). Výučba filozofie v rámci technických odborov ako prostriedok humanizácie a globalizácie výučby. In: Acta Humanica, 1/2005, pp. 114-118. 